TAPROBANICA, ISSN 1800-427X. December, 2013. Vol. 05, No. 02: pp. 142-143.

(C) Taprobanica Private Limited, 146, Kendalanda, Homagama, Sri Lanka.

http://www.sljol.info/index.php/tapro

\section{Alectra chitrakutensis (Orobanchaceae) in Bundi District, Rajasthan, India}

While surveying floral diversity of Bundi district in southeastern Rajasthan, we noticed, on 6 March 2008, a parasite on the roots of Vitex negundo L.. The parasitic plant was seen at Rain village $\left(25^{\circ} 38^{\prime} 23.10^{\prime \prime} \mathrm{N}, 75^{\circ} 40^{\prime} 34.09^{\prime \prime} \mathrm{E}\right.$; $286 \mathrm{~m}$ a.s.l.) in Hindoli tehsil of Bundi District, $22 \mathrm{~km}$ north from Bundi, on a field bund. Terrain of the field was quite flattish having a small rainy seasonal nallah on its eastern edge that is close to a government primary school building. Vitex negundo L., Woodfordia fruticosa (L.) Kurz and Mimosa himalayana Gamble were commonly growing along the banks of the nallah and on bunds of the field. The site was continuously checked during winter, summer and rainy seasons to observe the species's growth pattern until 2011. The parasitic plant starts appearing in the root zone of $V$. negundo at the end of the rainy season, and fruits at the beginning of the summer season. Winter is the best time to see this plant when it flowers massively. This plant is an erect herb, with purple scale-like leaves and yellow, sessile flowers in a terminal raceme (Fig.1). The three purple streaks on each petal are diagnostic. Aerial parts of young plants initially appear greenish-white, but soon turn purple. The stems are rhizomatous with numerous axillary buds. On digging, fresh rhizomes are orange-yellow in colour. After drying, they become black. The species was identified as Alectra chitrakutensis (Rau) R. Prasad \& R.D. Dixit, 1993 with the help of flora of Madhya Pradesh (Mudgal et al.,1997). Locally it is known as negad ki bunti.

Sharma (2002) has studied flora of the Hadoti zone of Rajasthan which is composed of four districts viz., Kota, Bundi, Baran and Jhalawar, but he did not reported this plant in his flora. The species was not included in the flora of Rajasthan by Shetty \& Singh (1987, 1991, 1993).
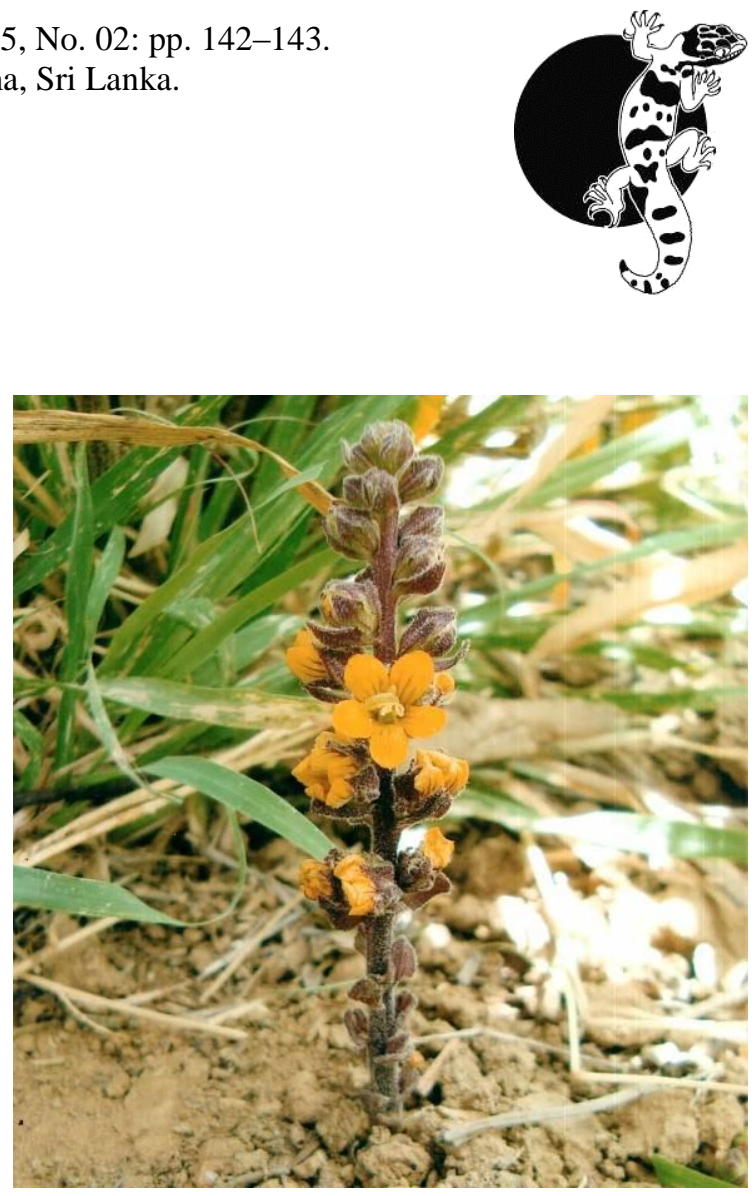

Figure 1: The parasitic Alectra chitrakutensis on root system of Vitex negundo.

Alectra chitrakutensis is a rare medicinal plant, known previously from the Chitrakoot region of India (Rau 1961; Saxena et al.,1969; Mudgal et al.,1997). Various aspects of this plant have been studied by Awasthi et al. (2008), Khanna \& Kumar (2007), Prasad \& Dixit (1993), Sikarwar (2007; 2009; 2010), Sikarwar et al., (2005) and Sikarwar \& Tiwari (2010). According to Sikarwar (2010) this plant is a critically endangered Indian endemic. It was known previously only from the Chitrakoot region of Madhya Pradesh and from Uttar Pradesh (Rau, 1961; Saxena et. al., 1969). Our population represents a range extension of around 550 kilometers to the west. Since it is an obligatory root parasite on Vitex negundo, further exploration of the distribution range of $V$. negundo in southeastern Rajasthan may reveal additional occurrences.

Our voucher specimen (Satish Kumar Sharma 111893, FRLH) was deposited in the herbarium of the Foundation for Revitalisation of Local Health Traditions, Bangalore (FRLH), for further reference. 


\section{Acknowledgements}

Authors are thankful to K. Ravikumar (Asst. Director, National Herbarium of Medicinal Plants \& Repository of Raw Drug, Bangalore), K. L. Sharma (Government Ayurveda College, Gwalior), and R. L. S. Sikarwar (Arogyadham Deendayal Research Institute, Chitrakoot) for helping in authentification of the species.

\section{Literature cited}

Awasthi, A. K., A. Gupta and A. K. Goel, 2008. Alectra parasitica var. chitrakutensis: A rare traditional remedy for leucoderma and virility in Chitrakoot region of Uttar Pradesh. Ethnobotany, 20: $154-156$.

Khanna, K. K. and A. Kumar, 2007. Taxonomic status of Alectra chitrakutensis (Rau) R. Prasad \& R. D. Dixit (Scrophulariaceae). Journal of Economic \& Taxonomic Botany, 31: 536-538.

Mudgal, V., K. K. Khanna and P. K. Hajra, 1997. Flora of Madhya Pradesh. Botanical Survey of India, Calcatta: 201-202.

Prasad, R. and R. D. Dixit, 1993. An endemic medicinal parasite from Madhya Pradesh under threat of extinction. Pp. 185-187, In: S. Pramod (ed.). Rural Reconstruction, Ecosystem and Forestry. M.G. Chitrakoot Gramodaya University, Chitrakoot.

Rau, M. A., 1961. Occurrence of Alectra parasitica A. Rich in India-A new variety of Banda district, U. P. Bulletin of the Botanical Survey of India, 3: 25-27.

Saxena, H. O., G. S. Shukia and P. S. Indorkar, 1969. Occurrence of Alectra parasitica A. Rich var. chitrakutensis Rau in Madhya Pradesh. Indian Forester, 95: 485-486.

Sharma, N., 2002. The flora of Rajasthan. Aavishkar Publishers, Jaipur: 280.

Shetty, B. V. and V. Singh, 1987. Flora of Rajasthan. Vol. I. Botanical Survey of India: 1451.

Shetty, B. V. and V. Singh, 1991. Flora of Rajasthan. Vol. II. Botanical Survey of India: 453-860.

Shetty, B. V. and V. Singh, 1993. Flora of Rajasthan. Vol. III. Botanical Survey of India: 861-1246.
Sikarwar, R. L. S., 2007. Exsitu conservation of Alectra chitrakutensis (Rau) R. Prasad \& R.D. Dixit. Current Science, 92: 1485-1486.

Sikarwar, R. L. S., 2009. Taxonomic status of Alectra chitrakutensis (Rau) R. Prasad \& R.D. Dixit. Journal of Economic and Taxonomic Botany, 33: 814-817.

Sikarwar, R. L. S., 2010. The herbal garden and herbarium of Arogyadham, Deendayal Research Institute, Chitrakoot, Dist. Satana, M.P. Phytotaxonomy, 10:139-142.

Sikarwar, R. L. S. and A. K. Tiwari, 2010. Exploitation, utilization and conservation of endemic and critically endangered ethnomedicinal plant species Alectra chitrakutensis in the Chitrakoot region. Ethnobotany, 22: 125-127.

Sikarwar, R. L. S., A. Jaiswal and V. Kumar, 2005. Medicinal uses of Alectra chitrakutensis. Journal of Tropical Medicinal Plants, 6: 93-97.

Submitted: 01 May 2013, Accepted: 12 Oct. 2013 Sectional Editor: James L. Reveal

S. K. Sharma ${ }^{1} \&$ R. C. Bhutya ${ }^{2}$

\footnotetext{
${ }^{1}$ Wildlife Sanctuary Jaisamand, Jaisamand Post, Udaipur District, Rajasthan 313905, India Email: sksharma56@gmail.com

${ }^{2}$ Govt. Ayurveda Hospital, Bhiya, Bundi District, Rajasthan 323002, India Email: rameshbhutya@gmail.com
} 